\title{
ASSESSMENT OF WEALTH DIVERSITY (CASE OF LITHUANIA)
}

\section{ONA GRAŽINA RAKAUSKIENE், VAIDA SERVETKIENE், LINA VOLODZKIENÉ}

\begin{abstract}
:
The high level of income and wealth distribution in the world is recognized as a phenomenon that leads to negative economic and social consequences. The imperfection of redistribution levers in the economy has created conditions for the concentration of resources, material goods and wealth in small population groups. Today, the economic system is not focused on majority of the population, and therefore the high level of inequality and its consequences for economic growth, well-being and human development cannot be ignored. In this context, too high economic inequality in Lithuania is one of the most sensitive problems of the country; Lithuania is an anti-leader in the European Union according to economic inequality.

Conventionally, economic inequality is measured using such methods as distribution of income and consumption of the population, however, to find out the real level of inequality, wealth diversity should be studied as well. The main purpose of this article is to identify and emphasise wealth diversity as an inseparable part of economic inequality in Lithuania and, as a result, the poor quality of life and obstacles in the way of economic progress as well as to compare wealth inequality with income inequality in Lithuania.

The authors organised a representative poll of Lithuanian citizens and used a certain survey to collect information about the dwelling-places or other types of assets owned by the respondents as well as to evaluate wealth diversity in the country. The results show that the edge value of the assets owned by the representatives between I and X deciles differs by 16.9 times. However, comparing the average prices of dwelling-places in deciles I and $X$, the difference amounts to 7.2 times. Assessing all types of assets, including accommodation, land, durable goods, etc., it has been revealed that the distribution of wealth exceeds the limit of income and consumption distribution established by various statistical organisations and by the authors themselves. The decile ratio (in relation to deciles I and $X$ ) equals to 40.8 , thus, it considerably exceeds the level of income and consumption inequality.
\end{abstract}

\section{Keywords:}

assessment of wealth diversity, assessment methodology, wealth inequality, wealth distribution, economic inequality, income inequality.

JEL Classification: D63, E21, P46

\section{Authors:}

ONA GRAŽINA RAKAUSKIENĖ, Mykolas Romeris University , Lithuania, Email: ona.rakaus@gmail.com VAIDA SERVETKIENĖ, Mykolas Romeris University, Lithuania, Email: vaida.servetkiene@gmail.com LINA VOLODZKIENĖ, Mykolas Romeris University, Lithuania, Email: lina.volodzkiene@gmail.com 


\section{Citation:}

ONA GRAŽINA RAKAUSKIENĖ, VAIDA SERVETKIENĖ, LINA VOLODZKIENĖ (2019). ASSESSMENT OF WEALTH DIVERSITY (CASE OF LITHUANIA). International Journal of Economic Sciences, Vol. VIII(1), pp. 106-130., 10.20472/ES.2019.8.1.008 


\section{Introduction}

In the last two decades, the growing economic inequality in the global economy as well as individual countries has reached an unprecedented level. According to the data of world economists, $1 \%$ of the planet's population have more assets than the remaining $99 \%$. In the USA, $1 \%$ of the wealthiest inhabitants own $40 \%$ of all the country's assets. The eight richest oligarchs in the world (four of them Americans) have concentrated the same amount of common wealth as the other 3.6 billion of the planet's population (Stiglitz, 2015). In addition, the income of the richest population is growing at a much faster rate than that of the others. Inequality that leads to negative economic, demographic, social and political consequences is becoming one of the world's greatest threats.

Economic inequality reduces social and economic welfare. Income and consumption inequality as well as uneven income distribution not only deny the principles of social justice but also limit people's access to and possibilities of acquiring education, proper upbringing, cultural background, a high-quality dwelling-place and a positive environment. Economic inequality has a particular negative impact on young people in developed as well as underdeveloped countries. According to the estimates by experts from the World Forum in Davos (2016), in 25 fast developing countries 540 million young people will be poorer than their parents. Experts predict an increase in social dissatisfaction as well as an increase in violence, populism and isolation. This process is already visible in Europe.

Inequality in the allocation of resources remains one of the most pressing challenges in the Lithuanian economy. This problem became particularly acute after the 2008 global financial crisis, which had a huge impact on the country. Lithuania is one of the anti-leaders in the EU in terms of income distribution. The income gap between the rich and the poor is increasing and poverty remains a serious problem.

In 2016, scientists of the Mykolas Romeris University (MRU) Life Quality Laboratory conducted a research on economic inequality and completed a survey of the Lithuanian population in order to analyse the actual level of wealth distribution and unequal distribution of material living conditions. They also compared the research results with the previously known information.

The authors of this paper have analysed economic inequality not only on the grounds of income and consumption distribution but also on the grounds of differences in material living standards that are related to individuals' disposal of wealth and their living conditions. The authors have decided to choose their own methods to determine this distribution, evaluating it by a single household's:

1. Wealth diversity mainly defined by the market value of a household which is at the disposal of individuals;

2. Provision of durable goods;

3. The occurring rate of economic challenges faced by the individuals.

The main purpose of this article is to identify and emphasise wealth diversity as an inseparable part of economic inequality in Lithuania and, as a result, the poor quality of life and obstacles in the way of economic progress as well as to compare wealth inequality with income inequality in Lithuania. 


\section{Theoretical aspects of socio-economic inequality}

Recent research shows that economic inequality hampers economic growth and quality of life of the population._Representatives of the neoliberal economy model argue that in a market economy inequality is inevitable as long as the economy is growing and its level of development is still low. However, global theoretical and practical research shows that such provisions are wrong. The studies concluded (Reich, 2010; Stiglitz, 2010, 2015; Sen, Fitoussi, 2010; Salverda, Nolan, Smeeding, 2013; Deaton, 2013; The World Bank, 2011 , etc.) have revealed the fact that a high level of inequality stops economic growth. Inequality, managed by a regressive tax system and other means of income distribution, significantly increases the income of the rich and reduces the income of all the remaining population, impeding the majority of the population. For this reason, the economy is ineffective and reduces opportunities for investment and innovation.

J.E. Stiglitz, a Nobel laureate in economics, submitted the report "Rewriting the Rules of the American Economy" (2015), in which hestates that inequality is not inevitable - it is not a social problem but an economic one. Inequality is not a price for economic growth, as liberals say, but is a cause of slowing economic growth. The greater the inequality, the lower the economic growth, says J.E. Stiglitz (2015). Inequality, according to J.E. Stiglitz (2015), is a systemic problem, a feature of the economic system.

Two main conclusions were made in J.E. Stiglitz's report: firstly, inequality is the result of ongoing economic policies favoring the rich people; secondly, these problems are not caused by one fragmentary factor, such as corporate tax, health or labour market reforms. They are determined by a set of factors and their system. That is why the fight against inequality requires a systemic solution in many areas - financial reform, corporate governance, tax policy, anti-trust policy, monetary, education, social and health policy and legal regulation of labour relations.

Similar questions are raised by $\mathrm{R}$. Reich, claiming that the main reasons of the global economic crisis are not the increase in national debts or the people' inability to live within their means. It is caused by high economic inequality when the growth of GDP is based on an unjustified increase in the income of the rich (Reich, 2010). Reich's research has shown that over the past 30 years the boom in lending has been accompanied by a growing gap between the richest US population and all others. The 2008 global financial crisis was the result of an increasing improper distribution of income.

Economic inequality stops economic growth at the same time negatively influencing the general well-being of society. Research shows that the distribution of the created product ignoring social justice not only stops economic growth and decreases the state budget revenue, but also negatively affects the quality of life of the population - demographic processes, health, material situation of people and access to education. In this context, it is not about any inequality, which by itself promotes development and competition, it is about extreme inequality that is treated as excessive inequality.

According to the World Bank's research (2011), inequality is considered to be excessive when it reaches $30-40 \%$ of the Gini coefficient level. Excessive inequality is not just deep inequality ('deep' does not mean excessive); inequality is considered to be excessive 
when it does not stimulate but hinders economic growth and quality of life and has negative social and economic consequences.

Excessive inequality, first and foremost, creates such negative social consequences as the 'poverty trap': people realize that they cannot break out of it, there are not enough strong social and economic impulses, and the human motivation for active involvement disappears. Other negative phenomena, such as suicide, cardiovascular diseases, crime, etc., then increase.

In recent years, inequality has been increasingly perceived as affecting the quality of human potential. It is claimed that inequality not only hinders economic growth and reduces the quality of life, but also the quality of human capital, i.e. it hinders human development.

Inequality increases the insecurity and vulnerability of society and the state. The World Bank's research (2011) has shown that two problems are particularly relevant to people insecurity and vulnerability. Vulnerability is perceived as a threat of a fall in living standards and deprivation.

One of the factors that contributes the most to the growing vulnerability is the economic inequality where low-income earners cannot overcome the difficulties of life. 'We have to look at inequality not as a moral problem, but as an economic challenge that is closely linked, firstly, to economic growth and, secondly, to an increase in vulnerability' (Stiglitz, 2015).

The world-renowned scientist T. Piketty claims that inequality is one of the key drivers of terrorism. When oil revenues started to concentrate in just a few countries with relatively few populations: in the region between Egypt and Iran, including Syria, several monarchs control over $60-70 \%$ of all assets, where only $10 \%$ of the population of this huge region lives..

Economic growth does not guarantee the improvement of social welfare, as the redistribution of gross national income determines the emergence of income, consumption and wealth inequality due to the different understanding of social justice and social and economic policy implemented in a country. The consequences of highly unequal income and resource distribution include the polarisation of the population, high rate of distribution and high level of poverty. The quality of social life rapidly deteriorates due to the increase in inequality, jealousy, competition, capitalisation of human relations, neglection of confidence and lack of empathy among individuals. These factors should become the focus of attention in every country. Moreover, all countries around the world should establish such political systems that could reduce economic inequality, income and wealth distribution and tension among individuals and that could ensure equitable living conditions and a high quality of life for their members as well as sustainable economic growth.

\section{Methodology}

After analyzing contemporary scientists' attitudes towards inequality, the authors present a concept of economic inequality which consists of basic provisions of economic inequality as well as a systemic concept. 
The main provisions of the economic inequality concept suggested by the authors are:

- Economic inequality includes the distribution of income, consumption, savings, material living conditions and wealth as well as unequal possibilities to acquire public good (education, health care, various services relating to culture, social services), depending on economic, social, demographic, psychological factors and capabilities at macro (state) and micro (social groups and individuals) levels.

- Economic inequality is not only the result of social, demographic and economic processes, but also a consequence of the economic policy being implemented. Inequality is not inevitable - it is a cumulative result of unjust policies (Stiglitz, 2015). Wealth and income inequality is not only the result of economics - it is the result of politics (Piketty, 2014).

- Inequality can be justified (normal) and excessive. A certain degree of inequality might be justifiable if inequality encourages individuals to improve, compete, save and invest money in development (for example, better education or wage differences can lead to human capital accumulation or economic development despite income inequality). However, an increasing level of inequality becomes a concern when it reduces a person's chances to acquire a better education or profession, when individuals are made to limit themselves to being submissive and self-secure, which ultimately leads to inadequate distribution of resources, corruption and nepotism. Excessive inequality does not necessarily mean a high level of inequality (high inequality is not necessarily excessive). Excessive inequality is a process which stops economic progress instead of encouraging it and leads to socially and economically-related negative consequences. It has a negative impact on economic development, welfare and various human resource processes.

- Economic inequality includes differences in material living conditions and wealth diversity in society. In scientific literature, two concepts are often distinguished: income inequality and wealth inequality. However, these concepts are interrelated, as often the wealth and the ability to acquire it depends directly on income. On the other hand, the authors believe that this distinction is not exhaustive, and given that both income inequality and wealth inequality are part of economic inequality, there are other equally important components of the phenomenon - consumption, savings and accessibility of public goods and services.

- Uneven distribution of wealth and income in the current generation creates unequal opportunities for future generations. Children of poor parents have much lower and poorer access to education, culture and health services, capacity building, which can lead to limited future professional career conditions, lower material and social status.

- The authors emphasize the important psychological aspects of inequality. Reducing human vulnerability, strengthening self-security and resilience to life challenges largely depends on psychological characteristics - one's initiative, way of thinking, positive attitude towards oneself and the world and satisfaction with life; also, on economic and financial behaviour - consumption, saving, physical and psychological health. Excessive inequality can lead to a sense of life 
dissatisfaction, a sense of lack of happiness, depression and negative psychological and physical health consequences.

- To reduce inequality, the key guidelines are: firstly, the implementation of macroeconomic policies geared towards full employment and the pursuit of sustainable fiscal policies aimed at improving the quality of life of the majority of the population; secondly, the reduction of vulnerability and the development of resilience to life challenges through raising the level of education, dissemination of knowledge and capacity building.

The concept and the structural basis of the economic inequality proposed by the authors consists of three levels: firstly, the factors that determine economic inequality; secondly, the content of economic inequality and the structure in which the object of the research is formed; thirdly, the consequences of inequality for the country's economic and social progress and quality of life: the main economic, social and psychological consequences and guidelines and measures for reducing inequality.

Figure 1. Factors causing economic inequality

\section{FACTORS CAUSING ECONOMIC INEQUALITY}

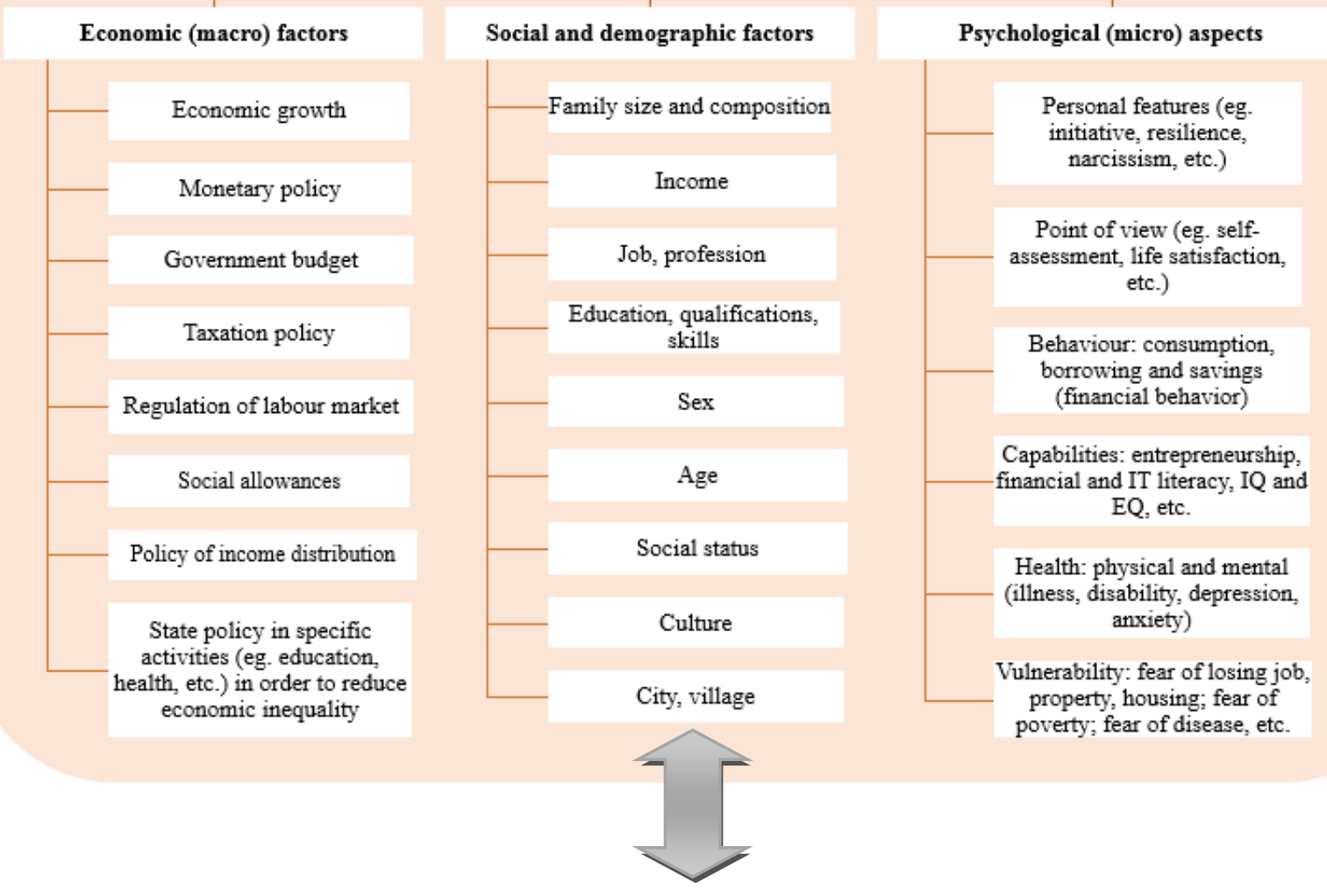


Figure 2. Structure of economic inequality

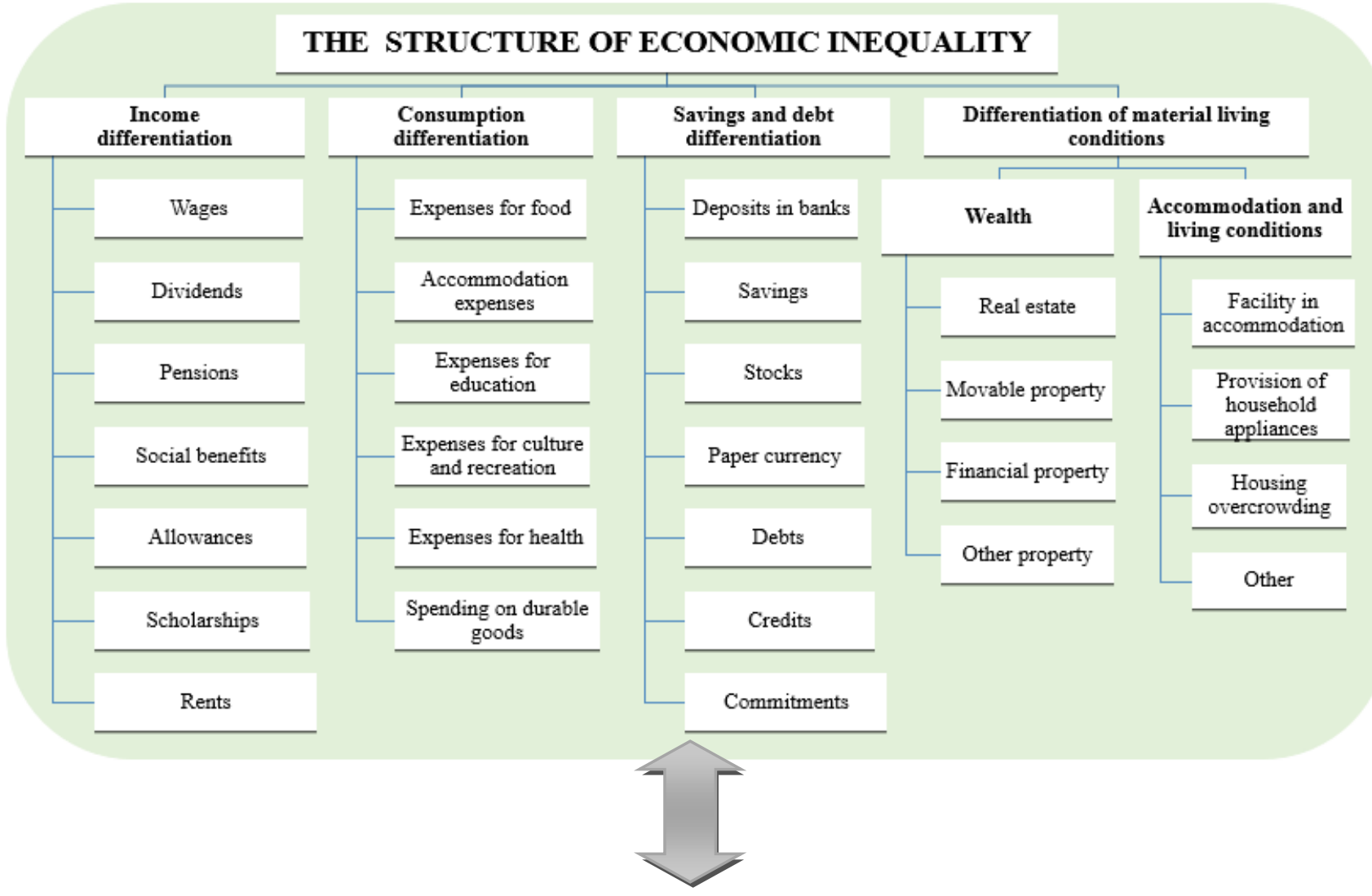

Figure 3. Consequences of inequality for the country's economic and social progress and quality of life

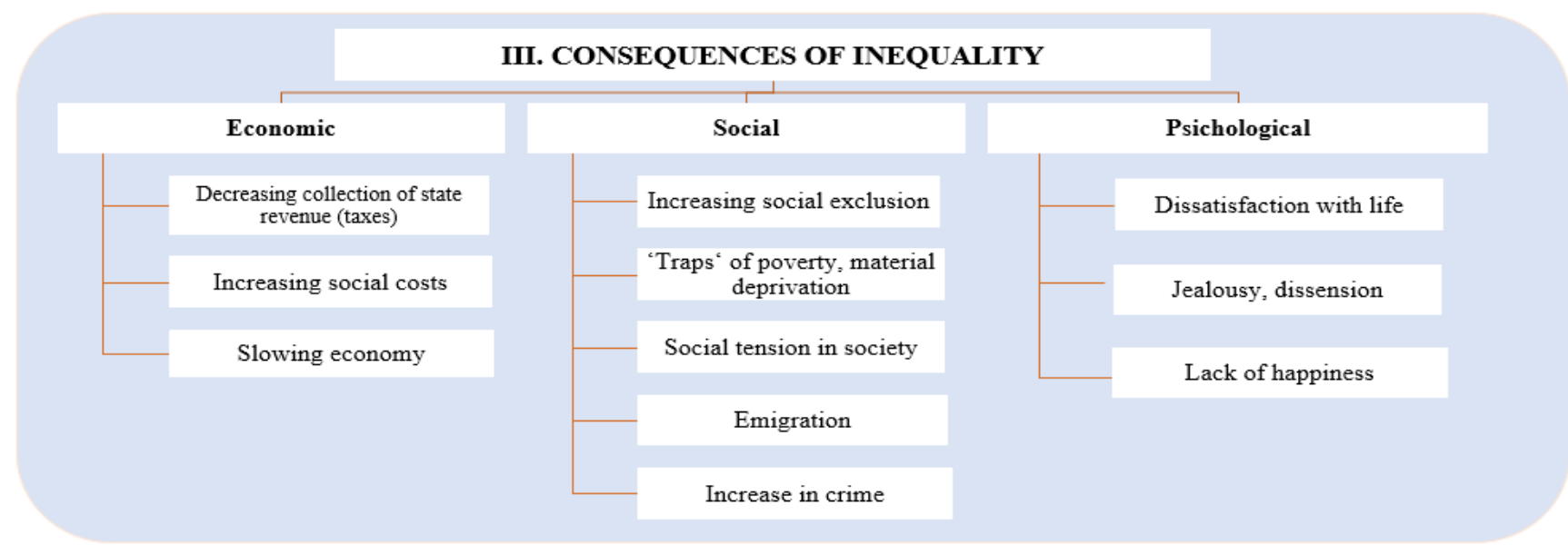

Source: Created by the authors

One of the most important aspects of the proposed concept is the distribution of material living conditions and wealth diversity. Accumulated and newly created assets are the basis for increasing the country's economic potential, which determines its development 
potential. The term 'wealth' is used in the sense of all material values. Theoretically, the wealth concept includes cash, bank deposits, other liquid assets, stocks and bonds, business shares, owner-occupied property or any other real estate, as well as durable goods, including antiques, art and jewelry. The wealth classification proposed by the authors focuses on tangible assets: the differentiation of real estate, highlighting the importance of housing, and the correlation with the quality of life. Meanwhile, movable and other types of assets are to be treated as directly related to incoming income and are therefore not considered separately.

Analysis of the differentiation of real estate, with emphasis on residential importance, and the correlation with the quality of life is one of the key aspects of the research. The influence of the latter factors on the quality of life has never been directly analyzed and assessed, but it is often assumed that this influence is huge. After assessing the importance of property, it is possible to formulate the state policy in the interest of the society and the welfare of every person.

It should be emphasized that wealth is distributed more unevenly than income or consumption. The distribution of disposable income by the Gini coefficient in OECD countries ranges from 0.30 to 0.50 , while the overall wealth distribution by the Gini coefficient ranges from 0.50 to 0.80 . Wealth and income correlate, and the high level of concentration highlights the issue of economic inequality (Davies, 2013).

\section{The presented concept of economic inequality - provisions and systemic conception - forms the basis of the research methodology.}

Firstly, the proposed concept allows a more accurate assessment of the inequality: not only the traditionally valued inequality of income, but also the wealth inequality and material living conditions.

Secondly, one of the key findings of the research is the assessment of wealth diversity. Many different methodologies are used to measure wealth inequality in the world but approaching the accurate wealth diversity is difficult. The authors propose their approach - the methodology of assessment of wealth diversity based on the results of sociological research of the Lithuanian population.

The aim of the research is to investigate the factors influencing the wealth inequality of the property of the Lithuanian population, the diversity of material living conditions of various Lithuanian social groups and its consequences for the country's economic and social development and the quality of life of the population.

The population under investigation - Lithuanian residents aged 18 and over.

Sample size - at least 1000 permanent residents of Lithuania.

Investigation method - a representative questionnaire of Lithuanian residents, conducted by direct interview at the respondent's home, using pre-prepared questionnaires in which the interviewers record the answers of the respondents. The results reflect the opinions and distribution of the population of Lithuania according to age, sex, place of residence, education and purchasing power.

Selection method -multi-level, probabilistic sampling is used to select respondents, so that every Lithuanian resident has the same probability of being interviewed, taking into 
account the age of 18 years and older, and the distribution of the Lithuanian population by residence, age, gender and education.

In assessing the results, it is necessary to pay attention to the statistical error. This is due to the selection of respondents and not to the continuous survey. This error is calculated mathematically. The table below shows errors in the number of respondents and the distribution of responses. The highest statistical error in the responses of all respondents (1000 people) is $\pm 3.1 \%$ (at $95 \%$ reliability level).

Table 1. Values for statistical errors for different results

\begin{tabular}{|l|c|c|c|c|c|c|c|c|c|}
\hline & $\%$ & $\%$ & $\%$ & $\%$ & $\%$ & $\%$ & $\%$ & $\%$ & $\%$ \\
\hline $\mathrm{N}$ & 3 & 5 & 10 & 15 & 20 & 25 & 30 & 40 & 50 \\
\hline 100 & 37 & 95 & 90 & 85 & 80 & 75 & 70 & 60 & 50 \\
\hline 200 & 2.4 & 4.4 & 6.0 & 7.1 & 8.0 & 8.7 & 9.2 & 9.8 & 10.0 \\
\hline 300 & 2.0 & 2.5 & 4.2 & 5.0 & 5.7 & 6.1 & 6.5 & 6.9 & 7.1 \\
\hline 400 & 1.7 & 2.2 & 3.0 & 3.6 & 4.6 & 5.0 & 5.3 & 5.7 & 5.8 \\
\hline 500 & 1.5 & 1.9 & 2.7 & 3.2 & 3.6 & 3.3 & 4.6 & 4.9 & 5.0 \\
\hline 750 & 1.2 & 1.6 & 2.2 & 2.6 & 2.9 & 3.2 & 3.1 & 4.4 & 3.6 \\
\hline 1000 & 1.1 & 1.4 & 1.9 & 2.3 & 2.5 & 2.7 & 2.9 & 3.1 & 3.7 \\
\hline
\end{tabular}

Source: Created by the authors

Principles of forming a questionnaire._During the survey, objective data (e.g. gender, income size, type of housing, etc.) are collected when a certain fact or condition is identified, also subjective assessment is made by the respondent (e.g. lack of income, ability to pay bills, borrowing rate, assessment of social status, happiness, selfconfidence, etc.).

A special questionnaire adapted for Lithuania was compiled using both questionnaires prepared by the project researchers and validation tools validated by the American Psychologist Association to determine how economic inequality is related to the psychological profile, as well as the resistance related to the elements of the psychological profile of the person, psychological well-being and social assessment of the economic situation. In analyzing the data, relationships between the economic inequality of the population according to income and subjective self-attribution to a particular socioeconomic situation group (subjective stratification) as well as the psychological profile are determined.

The questionnaire was tested during a pilot survey, after which it was adapted to the Lithuanian population:

- by modifying the questionnaires of validated evaluation instruments, including additional issues or by abandoning some, taking into account the habits and attitudes of Lithuanian society (e.g. issues related to the propensity to invest, plan expenses);

- by adjusting response options (e.g. response intervals, frequency ranges) to the questions that respondents had difficulties in answering during the pilot interview (e.g. by detailing consumption costs, naming frequencies, etc.); 
- by modifying or omitting some of the questions that respondents avoided responding to in the pilot interview or provided inaccurate information (e.g. issues related to consumer spending, disposal of assets).

In conclusion, economic inequality is one of the most relevant issues of globalisation that has a negative impact on economic development and socio--economic progress. Wealth and material living conditions are an integral part of economic inequality and they might be recognised as essential needs. These needs and the ability to own them or have them at one's disposal determine a person's material and moral security, self-confidence, selfesteem and the corresponding quality of life. Thus, as a part of economic inequality, wealth and material living conditions in some cases might encourage, while in other cases - suppress the person's self-realisation and creative potential, as well as increase or decrease a country's economic development and the quality of life of its society.

\section{Income inequality}

According to the research, the distribution of income of the Lithuanian population is characterized by two peaks indicating that there are 'two Lithuanias' - one is characterized by a more even distribution of income and concentration of income in lower income intervals, while the other is characterized by higher income distribution and concentration in high income intervals. Each one has different dominant sources of income, different economic activity, patterns of economic behaviour, consumption standards, values, etc.

$10 \%$ of the rich population of Lithuania hold almost one third of total income. Meanwhile, more than two-thirds of the population get $40.5 \%$ of total income. $10 \%$ of the poorest have 11 times lower income than the $10 \%$ of the richest $(\mathrm{Kd}=11.04)$. This shows that the threshold of social patience has been reached, which represents high social tension in society. The comparison of consumption costs in decile groups shows slightly lower distribution - Kd is 9.01 .

The distribution of income by place of residence shows a more even distribution of income in rural areas than in the city. However, with increasing population numbers in cities and metropolitan areas, income inequality is increasing. The largest differences in the level of income are observed in the capital, where the distribution of income is characterized by 'two peaks'. In villages, the income distribution coefficient $\mathrm{Kd}$ is 9.3 , in towns it is 10.4 and in cities - 10.8. There are particularly marked differences between rural and metropolitan decile groups. The difference in revenue between deciles I is $20.5 \%$, and in the $X$ deciles even $31 \%$. This means that the income of the wealthy metropolitan population is one third higher than that of the rich rural population. This is confirmed by our survey data on average income: the lowest income level is in rural areas (average income - 555.8 EUR), it is larger in towns (610.6 EUR), while the income of the city population is relatively highest (699.8 EUR). Population income growth in deciles reflects the growth potential of the population and shows that they are much larger in metropolitan areas than in rural areas.

The majority of Lithuanian population $-43.4 \%$ dispose of only $10.0 \%$ of total income. $72.3 \%$ of the population of Lithuania dispose of up to 750 EUR (450 EUR on average), and only $26.6 \%$ of the population receive over EUR 750 revenue. The income of only 
$3.2 \%$ of the population is over 1500 EUR per capita. The Gini coefficient in Lithuania was calculated according to the authors' survey data in 2016 and it was $35.56 \%$. According to the World Bank's research, inequality is becoming surplus starting at $30-40 \%$ of the Gini coefficient level. This means that inequality in Lithuania is excessive and hypertrophied.

Income received by the Lithuanian population ensures meeting the minimum needs food, health and housing. However, people are not able to satisfy their higher needs due to the lack of income. The largest shortage of income is typical of the townspeople (70\%) and the smallest - of the inhabitants of metropolitan areas (37\%). Based on our research, a paradoxical conclusion has been reached: despite the level of youth income not being the lowest, there is the largest shortage of money for young people (67\%). With increasing age, satisfaction with available funds is decreasing, but remains significant (55\%). The lack of funds among women is higher than among men $-43.9 \%$ and $35.8 \%$ respectively. Only $10 \%$ of Lithuania's population are satisfied with their financial position.

\section{Evaluation of the wealth diversity in Lithuania}

In 2016, the authors organised a poll of Lithuanian citizens and used a certain survey in order to collect information about the dwelling-places or other type of assets owned by the respondents. The survey was organised on the basis of such wealth-defining parameters as the type of a dwelling-place, its size, construction year, location, also the respondents' disposal of other assets and their functions (farmstead, cottage, agricultural land parcel, plots of forest, shares, securities, works of art, jewelry, coinage, postage stamps or other collectable goods). The price of a dwelling-place or another type of assets can be estimated based on these parameters, however, the market price applicable at the time of the survey should also be taken into consideration. The respondents were also asked about how exactly they had acquired certain assets (with or without mortgage financing, whether it had been given as a gift, inherited etc.) as well as their proprietary rights.

Based on the data collected during the survey, it has been revealed that $85.2 \%$ of the respondents live in their own dwelling-places (853 respondents in total), $11.4 \%$ (114 respondents) live in rented dwellings, $8.7 \%$ of Lithuanians have a second dwelling-place and $34.9 \%$ of people have their own land parcel (household holding) larger than 5 ares.

It is worth noting that $96.6 \%$ of the respondents who receive pensions, $86.4 \%$ of the respondents who receive income from their own enterprises or farming activity and $81.1 \%$ of the respondents who are employees live in their own dwelling-places. A considerable part $-82.3 \%$ of the respondents who receive unemployment benefits, disability pensions or other social allowances also have their own private dwelling-places. However, $60 \%$ of the individuals whose main source of livelihood is ensured by child allowances do not own their own dwelling-places. More than one dwelling-place is owned mostly by the individuals who earn income from self-employment or farming activities (15.9\%), by those who are employed by other individuals (10.3\%) and who live off of old-age pensions $(7.8 \%)$, unemployment benefits, disability pensions or other social allowances $(2.5 \%)$. Land parcels (household holdings) larger than 5 ares are owned by more than a half of the respondents $(56.8 \%)$ who earn their income from private enterprises or farming activities, by $40.5 \%$ of pensioners, by $33.5 \%$ of the individuals who receive wages and by 
more than one fifth (21.5\%) of the Lithuanians whose main source of income is guaranteed by unemployment benefits, disability pensions or other social benefits and allowances.

The widespread tendency to refer to oneself as belonging to different socio-economic groups also proves the pessimistic attitude towards one's situation: some of the respondents think rather critically about their material living conditions, although the assets that they have at their disposal allow them to fulfill their essential needs.

Based on the subjective evaluation of a socio-economic situation, those who refer to themselves as the disadvantaged and being unable to live a respectable life actually have at their disposal the following: $90.6 \%$ of such respondents live in their own private dwelling places, $43.5 \%$ of the respondents own a car $(2.2 \%$ of them own two cars), $33 \%$ of the respondents have their own parcel of land (household holding) larger than 5 ares; moreover, they have at their disposal the following types of assets that could be sold, rented or pledged in case of need: $9.1 \%$ of the respondents have a farmstead, $14.1 \%$ have a cottage, $22.1 \%$ have an agricultural land parcel, $5.1 \%$ have a plot of forest, $5.8 \%$ have other types of assets (coinage, collections of postage stamps, amber, gold, etc.).

The respondents who refer to themselves as belonging to the poorest sections of society which are unable to meet their daily needs have at their disposal the following: $82.2 \%$ dwell in their own houses, $11.1 \%$ own a car and $15.6 \%$ have a private land parcel (household holding) larger than 5 ares.

\section{Figure 3. Proportion of the population in different socio-economic status groups (\%) who own a dwelling-place (based on subjective stratification)}

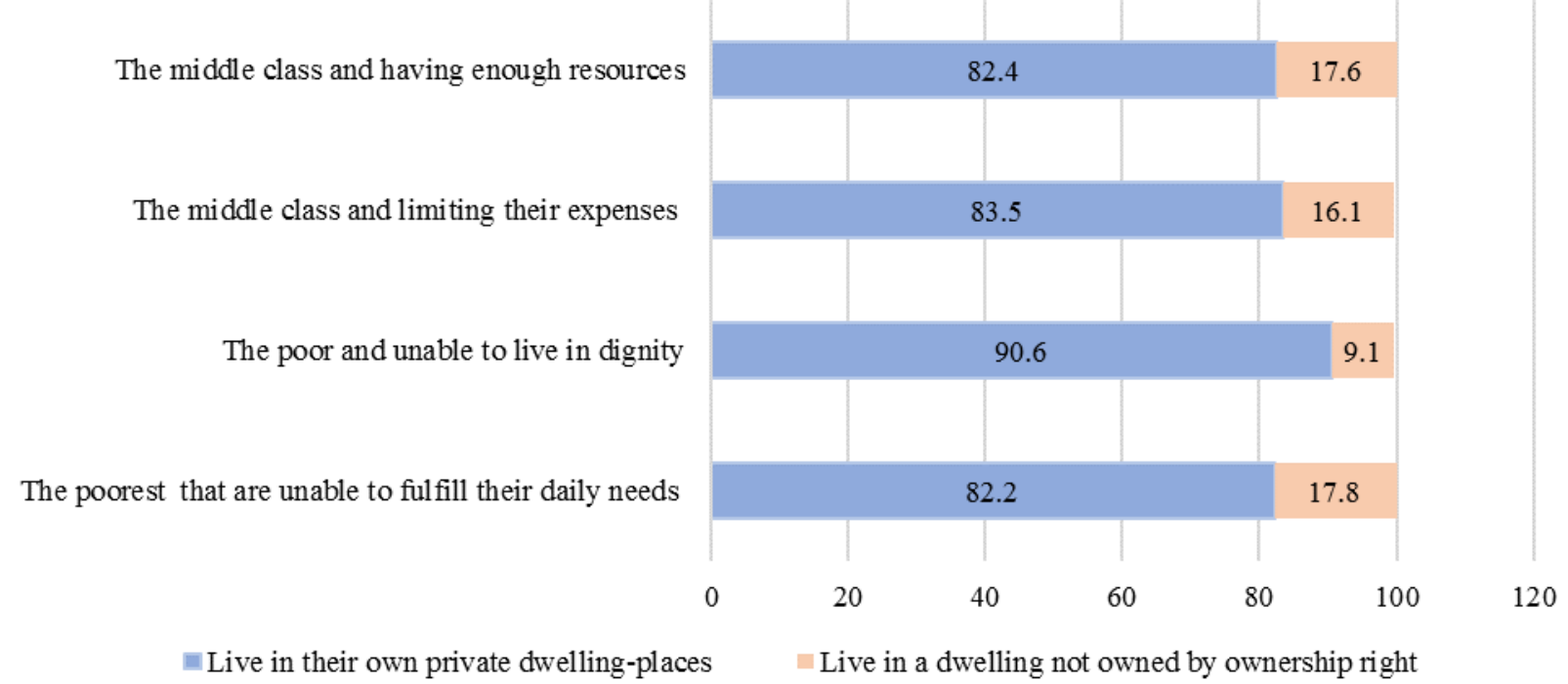

Source: Authors' research.

In addition, $82.4 \%$ of those who refer to themselves as belonging to the middle class and having enough resources (money) to lead a normal life as well as $83.5 \%$ of those who refer to themselves as belonging to the middle class and limiting their expenses 
(sometimes lacking money to lead a normal life) to live in their own houses, a similar proportion of the population who refer to themselves as belonging to the lower class (36\% and $37.1 \%$ ) have at their disposal a private land parcel larger than 5 ares.

Based on the location of a dwelling-place, it is clear that most dwellings are located in cities and small towns (respectively $91 \%$ and $95 \%$ ), rural areas $(84.4 \%$ ) and metropolitan areas $(93.3 \%)$.

Figure 4. Proportion of the population (\%), determined by the location of accommodation, who live in their own dwelling-place

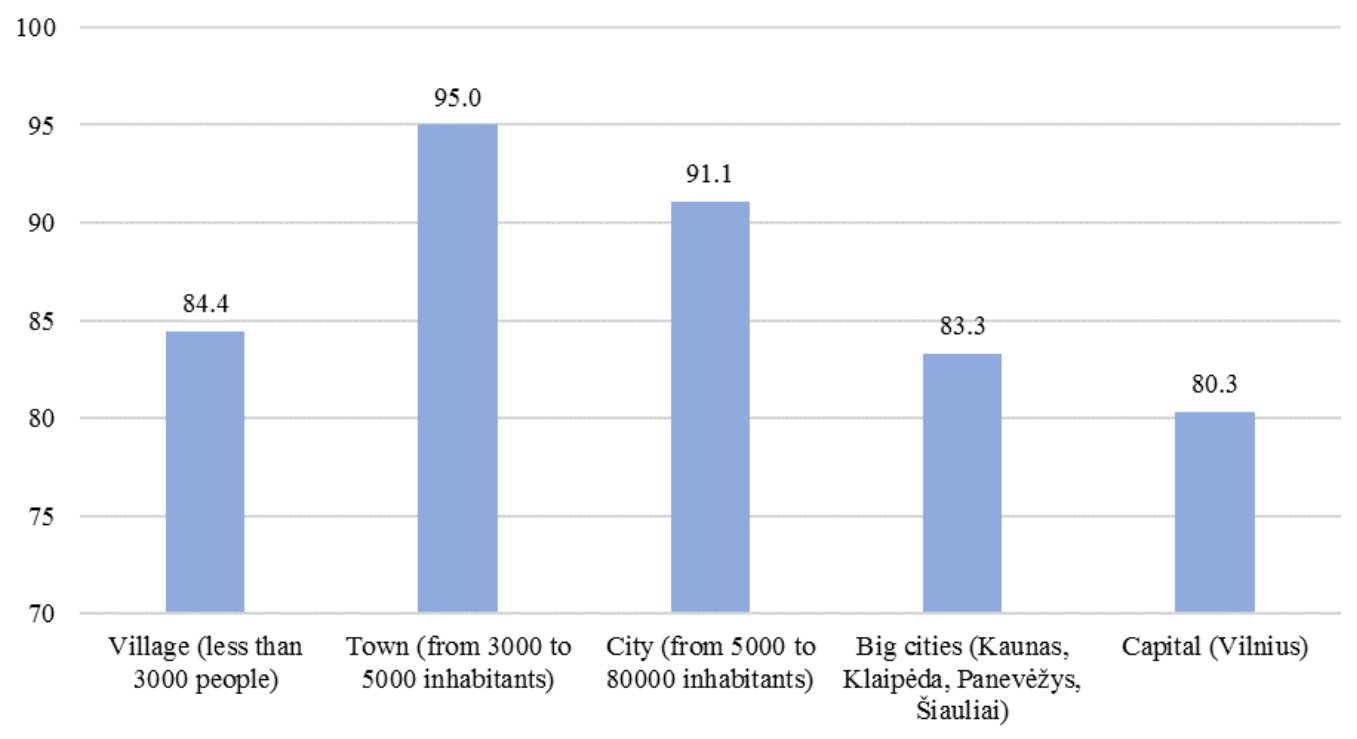

Source: Source: Authors' research.

The analysis of the data that were collected based on different age groups has proved that the ability to purchase a dwelling-place depends directly on a person's age - the older the individuals, the more likely they are to have their private accommodation.

There are no significant differences among different sexes in relation to their disposal of a private dwelling-place: $85.8 \%$ of the interviewed females and $84.7 \%$ of the interviewed males live in their own dwellings.

Figure 5. Proportion of the population (\%), determined by the age of a person, who live in their own dwelling-place 


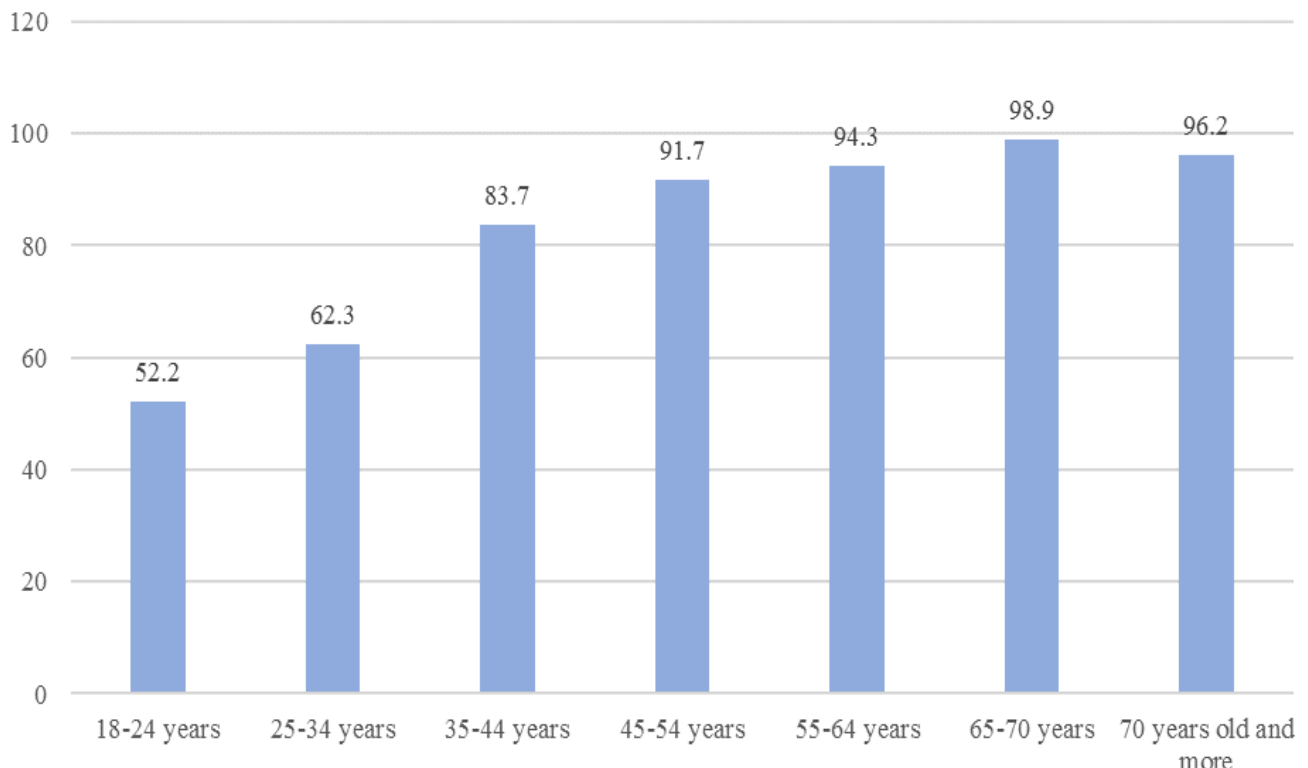

Source: Authors' research.

The inequality of wealth, expressed by the value of a private dwelling-place, is evaluated as follows: only the types of accommodation that had been purchased without mortgage financing, inherited or given as a gift (i.e., the types of accommodation (598 units) that had not been pledged or limited in any other way and belong to a single household by statutory rights of ownership) were included into the researched sample in the process of evaluating the inequality of wealth, expressed by the value of private accommodation.

Table 1. Differentiation of accommodation based on the way they have been purchased

\begin{tabular}{|l|c|c|}
\hline Total of housing owners / co-owners (N=723): & $\mathrm{N}$ & $\%$ \\
\hline Housing purchased without a financial loan & 472 & 65.3 \\
\hline Housing purchased with a financial loan & 119 & 16.5 \\
\hline Housing inherited, donated & 126 & 17.4 \\
\hline Do not know / did not answer & 6 & 0.8 \\
\hline Total: & $\mathbf{7 2 3}$ & $\mathbf{1 0 0 . 0}$ \\
\hline
\end{tabular}

Source: Source: Authors' research. 
Table 2. Distribution of wealth expressed by the value of accommodation in decile groups

\begin{tabular}{|c|c|c|c|c|c|c|c|c|c|c|}
\hline Decile & I & II & III & IV & V & VI & VII & VIII & IX & X \\
\hline $\begin{array}{c}\text { Average } \\
\text { housing } \\
\text { value in } \\
\text { decile (EUR) }\end{array}$ & 13592 & 18468 & 21793 & 26567 & 27260 & 33077 & 38143 & 50026 & 64715 & 97890 \\
\hline $\begin{array}{c}\text { Inter-decile } \\
\text { differences } \\
\text { (times) }\end{array}$ & & 1.35 & 1.18 & 1.22 & 1.02 & 1.21 & 1.15 & 1.31 & 1.29 & 1.51 \\
\hline
\end{tabular}

Source: Authors' research.

Based on the data on private accommodation provided by the respondents, it is evident that the minimum statistical value of a single dwelling-place (taking into consideration that the value of a dwelling-place is determined by the market value) ranges between EUR 9990 in the first decile and EUR 169200 in the tenth decile, thus differs 16.9 times. In comparison, average accommodation prices in the first and tenth deciles differ about 7.2 times, in the second and ninth deciles - 3.5 times, in the ninth and tenth deciles - 1.5 times. The differences between adjacent deciles are not that obvious, however, they become prominent when approaching the tenth decile.

Table 3. Decile ratios of wealth expressed by the value of specific accommodation

\begin{tabular}{|c|c|c|c|}
\hline $\mathbf{X} / \mathbf{I}$ & $\mathbf{I X} / \mathbf{I I}$ & $\mathbf{X} / \mathbf{V}$ & $\mathbf{X} / \mathbf{I X}$ \\
\hline 7.2 & 3.5 & 3.6 & 1.5 \\
\hline
\end{tabular}

Source: Authors' research.

Figure 6. Average value (EUR) of accommodation in different deciles

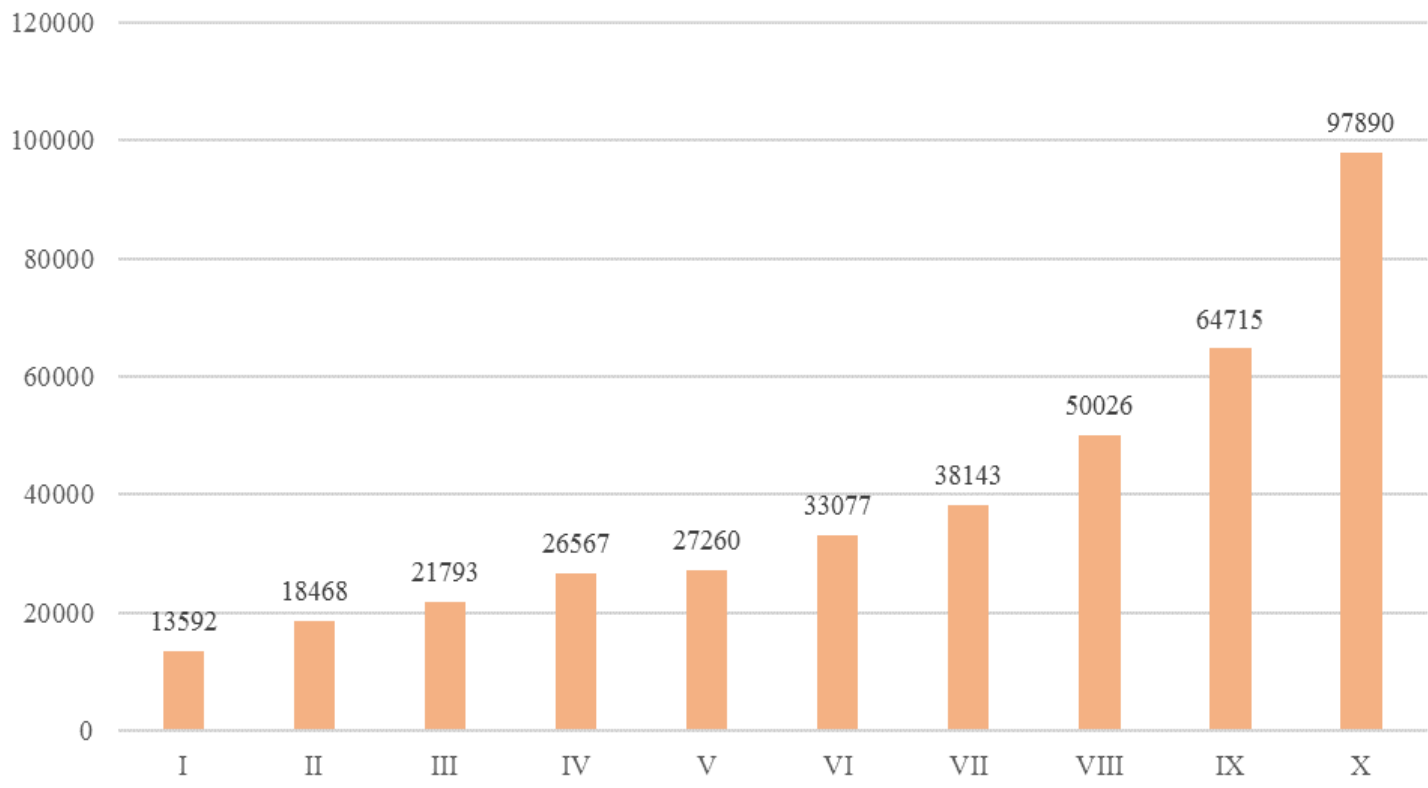

Source: Authors' research. 
Thus, it might be stated that the distribution of wealth that is realised by the value of accommodation is relatively high, i.e., the difference among the first and tenth decile groups is more than 7 times. However, it is worth noting that this evaluation is not entirely accurate considering the following limitations:

- the evaluated assets included only the type of accommodation that is owned by a household, i.e., the households that do not own any property (they comprise about $14.8 \%$ of the respondents) and the individuals who have purchased their dwellings with mortgage financing (approximately $12 \%$ of the respondents) have not been included in the sample of the research; thus, for the purposes of the evaluation, only the accommodation owned by $60 \%$ of the respondents has been taken into consideration no real estate, agricultural parcels, durable goods, works of art or other types of assets have been analysed;

- only the value of the main (first) dwelling-place has been evaluated, since the lack of data has prevented the researchers to include 58 more dwellings of secondary importance into the process of evaluation (during the survey, it was only recorded whether the respondents owned any other dwelling-places, however, not enough data about second dwellings were collected); taking into account the fact that about a half of these second dwellings are located in regions and provided that the minimum price of these dwellings amounts to EUR 20 000, the average value of assets in the tenth decile would be even higher and the difference between the first and tenth decile groups would increase by 8.7 times;

- the calculated prices of the dwellings belonging to the interviewed respondents are only tentative, based on the accuracy of such parameters as the construction year of a building, the type of the building, its location etc., as the market value and prices are not as detailed as the attributes included in the survey (e.g., the construction year of the building, also the fact that market prices are listed only for new and old housing).

Thus, the decile $(X / I)$ ratio (7.2 times) reveals only the approximate difference between the individuals who own dwellings in provinces and metropolitan areas. However, more significant wealth-related disparities among Lithuanian residents would be revealed if the analysed sample included the respondents who do not own any kind of accommodation, also the ones who own two or three different dwelling-places or those who have at their disposal other types of wealth (private land, shares, durable goods, etc.).

\section{Survey results: evaluation of inequality of wealth, expressed by the value of a private dwelling-place}

The more significant wealth-related disparities among Lithuanian residents could be revealed if the analysed sample included the respondents who do not own any kind of accommodation, rent a dwelling-place, have not paid their mortgage yet, but possibly have at their disposal other types of assets, such as a car, other durable goods, second dwellings, a private parcel of land (household holding), agricultural parcels, plots of forests, shares, securities, works of art, etc. According to the research data, the attribution of Lithuanians to different decile groups, based on the assets they have in their disposition, is as follows: 
Table 4. Differentiation of households in different deciles, based on the assets they have at their disposal

\begin{tabular}{|c|c|c|c|}
\hline $\begin{array}{l}\text { Deci- } \\
\text { les }\end{array}$ & $\begin{array}{l}\text { Description of a household that belongs to a certain } \\
\text { decile and has assets at its disposal }\end{array}$ & $\begin{array}{l}\text { Average } \\
\text { value } \\
\text { ofassets } \\
\text { (EUR) in a } \\
\text { certain } \\
\text { decile } \\
\text { group }\end{array}$ & $\begin{array}{l}\text { Diffe- } \\
\text { rences } \\
\text { among } \\
\text { adja- } \\
\text { cent } \\
\text { deciles }\end{array}$ \\
\hline I & $\begin{array}{l}\text { Households that do not own private dwelling-places or } \\
\text { do not pay rent for the place of residence, do not own a } \\
\text { car, however, have at their disposal the most necessary } \\
\text { durable goods. Almost } 36 \% \text { of this decile group own } \\
\text { assets that could be sold or pledged in case of need. }\end{array}$ & 2648 & \\
\hline II & $\begin{array}{l}\text { Households that do not own a private dwelling-place; } \\
\text { approximately } 70 \% \text { of the individuals belonging to this } \\
\text { decile group do not pay rent but have the most } \\
\text { necessary durable goods at their disposal; about } 90 \% \text { of } \\
\text { these individuals are able to purchase a car or other } \\
\text { durable goods. }\end{array}$ & 7420 & 2.80 \\
\hline III & $\begin{array}{l}\text { Households that do not own a private dwelling-place but } \\
\text { pay or are able to pay rent; more than } 70 \% \text { of the } \\
\text { individuals belonging to this decile group own a car, } \\
20 \% \text { of the individuals own a land parcel (household } \\
\text { holding) larger than } 5 \text { ares or any other real estate. }\end{array}$ & 10820 & 1.46 \\
\hline IV & $\begin{array}{l}\text { Households that own private dwelling-places whose } \\
\text { value ranges from EUR } 13 \text { to } 18 \text { thousand, depending } \\
\text { on a dwelling's location, its construction year, size and } \\
\text { type. }\end{array}$ & 15180 & 0.71 \\
\hline $\mathrm{V}$ & $\begin{array}{l}\text { Households that have purchased accommodations with } \\
\text { mortgage financing or are still paying mortgage; about } \\
14 \% \text { of this decile group own a second dwelling-place, } \\
48 \% \text { of people own a land parcel larger than } 5 \text { ares. }\end{array}$ & 17683 & 1.16 \\
\hline $\mathrm{VI}$ & $\begin{array}{l}\text { Households that own a private dwelling-place which has } \\
\text { been purchased without mortgage financing and whose } \\
\text { value ranges from EUR } 18 \text { to } 25 \text { thousand, depending } \\
\text { on the location of the dwelling-place, its construction } \\
\text { year, size and type. }\end{array}$ & 22412 & 1.48 \\
\hline VII & $\begin{array}{l}\text { Households that own a private dwelling-place which has } \\
\text { been purchased without mortgage financing and whose } \\
\text { value ranges from EUR } 25 \text { to } 29 \text { thousand, depending } \\
\text { on the location of the dwelling-place, its construction } \\
\text { year, size and type. }\end{array}$ & 27087 & 1.21 \\
\hline VIII & $\begin{array}{l}\text { Households that own a private dwelling-place which has } \\
\text { been purchased without mortgage financing and whose } \\
\text { market value is about EUR } 32 \text { thousand, depending on }\end{array}$ & 38830 & 1.43 \\
\hline
\end{tabular}




\begin{tabular}{|c|c|c|c|}
\hline & $\begin{array}{l}\text { the location of the dwelling-place, its construction year, } \\
\text { size and type. } 39 \% \text { of the individuals belonging to this } \\
\text { decile group own a private land parcel larger than } 5 \\
\text { ares. }\end{array}$ & & \\
\hline IX & $\begin{array}{l}\text { Households that own private land parcels larger than } 5 \\
\text { ares and a private dwelling-place which has been } \\
\text { purchased without mortgage financing and whose } \\
\text { market value is about EUR } 50 \text { thousand, depending on } \\
\text { the location of the dwelling-place, its construction year, } \\
\text { size and type. }\end{array}$ & 60261 & 1.55 \\
\hline$X$ & $\begin{array}{l}\text { Households that own a private land parcel larger than } 5 \\
\text { ares and a private dwelling-place which has been } \\
\text { purchased without mortgage financing and whose } \\
\text { market value is about EUR } 85 \text { thousand, depending on } \\
\text { the location of the dwelling-place, its construction year, } \\
\text { size and type. } 58 \% \text { of the individuals belonging to this } \\
\text { decile group also own a second dwelling. }\end{array}$ & 108028 & 1.79 \\
\hline
\end{tabular}

Figure 7. Average value of a single household's wealth in different deciles (EUR) 120000

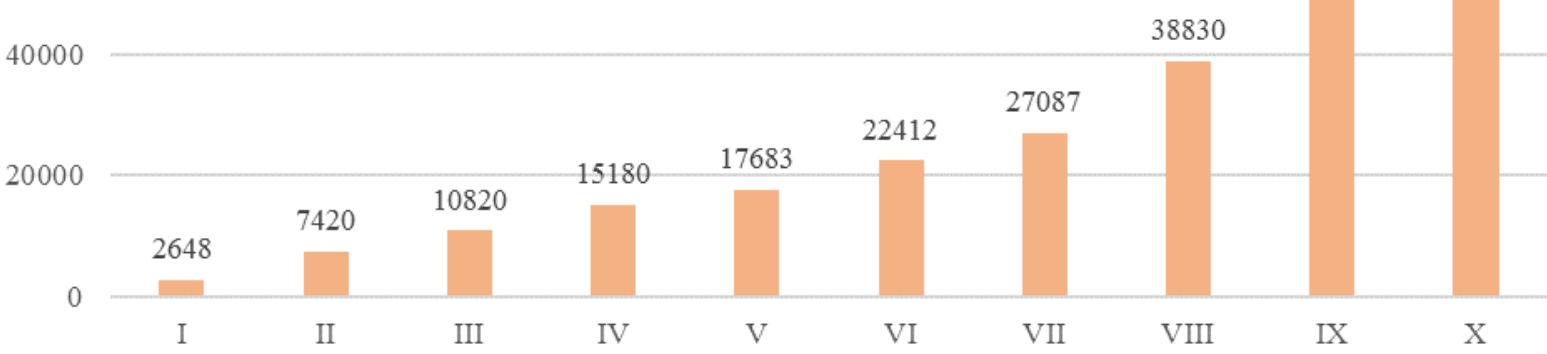

Source: Authors' research.

Based on the tentative evaluation made by the authors and considering the market prices of dwellings, land, durable goods and other types of assets in 2016 (the year in which the survey was conducted), also based on the data collected during the survey that have been mostly used for determining the average value of a single household's wealth, the authors have determined that the distribution of wealth exceeds the limits of income and consumption distribution established by various statistical organisations and by the 
authors themselves. The decile ratio (in relation to deciles I and X) equals to 40.8. It must be noted that it is impossible to determine and to objectively evaluate the average value of assets owned by a single household, as the respondents usually indicate their income by certain intervals and only reveal the fact whether or not they own any other type of assets, based on such parameters as the size of housing, its recency, etc.). There are neither data about the exact amount of income received by a household, nor data about the exact value of wealth that such a household has at its disposal.

Based on the answers provided by the respondents who are considered to belong to the upper class, it has been determined that $10 \%$ of the richest Lithuanians possibly have at their disposal about $34.8 \%$ of overall wealth in Lithuania; $1 \%$ of the richest Lithuanians have at their disposal $8.9 \%$ of overall wealth in Lithuania. Moreover, having estimated the differences among adjacent deciles, it is evident that the largest differences exist between deciles X and IX as well as between deciles I and II (2.8 times). This means that such significant differences among marginal deciles have an enormous impact on the indicators of wealth inequality.

\section{Table 5. Decile ratios of a single household's wealth}

\begin{tabular}{|c|c|c|c|}
\hline $\mathbf{X} / \mathbf{I}$ & $\mathbf{I X} / \mathbf{I I}$ & $\mathbf{X} / \mathbf{V}$ & $\mathbf{X} / \mathbf{I X}$ \\
\hline 40.8 & 8.1 & 6.1 & 1.8 \\
\hline
\end{tabular}

Source: Authors' research.

Having analysed the data about the private dwelling-places that have been purchased with mortgage financing, the following tendencies have become evident: according to the survey, the individuals living in the dwelling-places that have been purchased with mortgage financing comprise about $11.9 \%$ of all dwelling-places, $72.3 \%$ of which are apartments in blocks of flats. However, the differences of the dwelling-places that have been purchased with home loans is quite different from what was expected: a large number of the dwelling-places that have been purchased with home loans are located in rural areas and small towns (16\% and $22 \%$ respectively), $13.2 \%$ of such dwelling-places are located in cities with 5 000-80 000residents, $17.7 \%$ of the dwelling-places are located in metropolitan cities, such as Kaunas, Klaipèda, Panevėžys, Šiauliai. Only one fifth of all the private dwelling-places that have been purchased with home loans (19.7\%) are located in Vilnius. The area of such a dwelling-place is usually about 60-79 square meters $(42 \%)$ or $50-59$ square meters $(23.5 \%)$. Based on the data about the construction year, $38.7 \%$ of all the dwelling-places date back to $1971-1980$, whereas $22.7 \%$ of the dwelling-places were built in 1981-1990. $21.6 \%$ of all the respondents have indicated the repayment of a mortgage to be a heavy burden on the household, $43.1 \%$ of the respondents have indicated the repayment of a mortgage to be a low-scale burden on the household. 
Figure 8. Repayment of a home loan is a heavy burden on the following proportion of all households (\%)

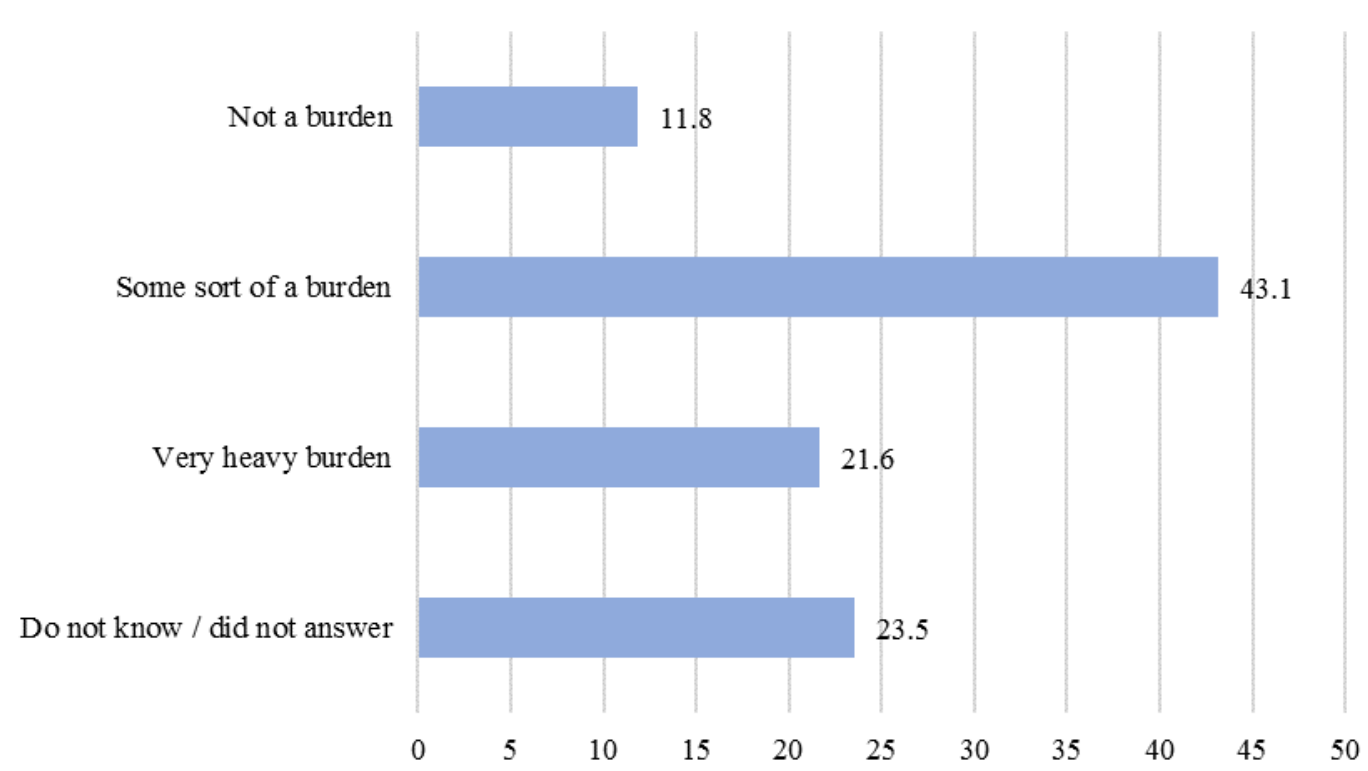

Source: Authors' research.

Based on the data collected during the survey, it has been revealed that $11.4 \%$ of the respondents rent their dwelling-place. The distribution of rented properties is the following: the respondents most often rent apartments in blocks of flats (81.6\%) and more than a half of these apartments (54.4\%) were built between 1961 and 1980 . Two thirds of the respondents (64.1\%) who rent housing are 18- to 34-year-olds, $66.7 \%$ of them work as contract employees, their wages being their main source of livelihood. It should also be noted that $7.9 \%$ of the residents who rent housing are pensioners, $8.8 \%$ of them live off of unemployment benefits, disability pensions or other social benefits and allowances. In order to evaluate the ability of a certain household to rent housing, it is essentially important to consider other home maintenance expenses as well. $46.5 \%$ of the respondents have indicated that they spend EUR 101-200 on average on home maintenance every month, $34.2 \%$ of the respondents spend up to EUR $100,14 \%$ of the respondents spend EUR 201-450 on home maintenance per month.

The Gini coefficient of wealth that is expressed by the value of housing is estimated as follows. The Gini coefficient $(G)$ is a relation between the figure's area, which is confined by the continuous (normal) distribution curve and the Lorenz curve, and the triangular's area, which is below the normal distribution curve:

$G=1-2 \sum_{i=1}^{k} d_{x i} d_{y i}^{K}+\sum_{i=1}^{k} d_{x i} d_{y i}$

where $-d_{x i}$ - the proportion of the $\mathrm{i}^{\text {th }}$ group of residents who were interviewed during this survey (i.e., in the given example - the number of residents who own 1-, 2-, etc. bedroom apartments); 
$d_{y i}$ - the proportion of the total volume of a certain parameter (apartment value) of the $\mathrm{i}^{\text {th }}$ group relating to the given sample;

$d_{y i}^{K}$ - the cumulative part of the attribute (apartment value) of the $\mathrm{i}^{\text {th }}$ group relating to the given sample.

Table 6. Distribution of wealth, expressed by the value of housing and the Gini coefficient in Lithuania

\begin{tabular}{c|c|c|c|c|c|c|c|} 
Decile & \multicolumn{2}{|c|}{ Housing } & \multicolumn{2}{|c|}{ Housing value } & \multicolumn{2}{c|}{ Product } \\
\hline & Number & Share & $\begin{array}{c}\text { Total } \\
\text { housing } \\
\text { value } \\
\text { (Eur) }\end{array}$ & Share & $\begin{array}{c}\text { Cumulate } \\
\text { d share } \\
d_{y i}^{K}\end{array}$ & & \\
\hline I & 60 & 0.101351 & 815521 & 0.034562 & 0.034562 & 0.003503 & 0.003503 \\
\hline II & 59 & 0.099662 & 1089641 & 0.046179 & 0.080741 & 0.004602 & 0.008047 \\
\hline III & 59 & 0.099662 & 1285759 & 0.054491 & 0.135231 & 0.005431 & 0.013477 \\
\hline IV & 59 & 0.099662 & 1951546 & 0.082707 & 0.217938 & 0.008243 & 0.021720 \\
\hline V & 59 & 0.099662 & 1608364 & 0.068163 & 0.286101 & 0.006793 & 0.028513 \\
\hline VI & 59 & 0.099662 & 1951546 & 0.082707 & 0.368807 & 0.008243 & 0.036756 \\
\hline VII & 59 & 0.099662 & 2250460 & 0.095375 & 0.464182 & 0.009505 & 0.046261 \\
\hline VIII & 59 & 0.099662 & 2951561 & 0.125087 & 0.589269 & 0.012466 & 0.058728 \\
\hline IX & 59 & 0.099662 & 3818192 & 0.161815 & 0.751084 & 0.016127 & 0.074855 \\
\hline X & 60 & 0.101351 & 5873413 & 0.248916 & 1 & 0.025228 & 0.101351 \\
\hline Total: & 592 & 1 & 23596003 & 1 & & 0.100141 & 0.393212 \\
\hline
\end{tabular}

Source: Authors' research.

The Gini coefficient of the distribution of wealth, expressed by the value of wealth, is calculated as follows (see formula No 1):

$\mathrm{G}=1-2^{*} 0.393212+0.100141=0.313717$.

The estimation of the Gini coefficient of the distribution of wealth, expressed by the value of wealth in metropolitan areas, is analogous:

$\mathrm{G}=1-2 * 0.368103+0.099919=0.363714$.

The Gini coefficient of the distribution of wealth, expressed by the value of wealth in various cities:

$\mathrm{G}=1-2^{*} 0.379817+0.100149=0.340515$. 
The Gini coefficient of the distribution of wealth, expressed by the value of wealth in rural areas:

$\mathrm{G}=1-2 * 0.388152+0.099469=0.313717$.

Table 7. Gini coefficient of wealth, expressed by the value of wealth

\begin{tabular}{|c|c|c|c|}
\hline Common & Big cities & Cities & $\begin{array}{c}\text { Towns, } \\
\text { villages }\end{array}$ \\
\hline 0.31 & 0.36 & 0.34 & 0.31 \\
\hline
\end{tabular}

Source: Authors' research.

Based on the calculations of the Gini coefficient of wealth inequality in rural areas, cities and metropolitan areas in Lithuania as well as in Lithuania in general and bearing in mind that the survey included only the respondents that own their dwelling-places, without taking into account the respondents that do not own accommodation or another type of real estate, land, financial assets, durable goods, works of art or intangible assets, it is evident that wealth inequality among different households has reached a rather high level, as the Gini coefficient exceeds the limit of 0.3, i.e., the theoretical margin of this particular coefficient. Thus, having considered the limits of this method of evaluating wealth inequality, it might be stated that the real level of wealth inequality in Lithuania already exceeds the existing levels of income and consumption inequality.

\section{Conclusions}

Inequality in the allocation of resources remains one of the most pressing challenges in the Lithuanian economy. However, in recent decades, especially since 2008, in the wake of the global crisis, economic inequality has been brought to the attention of world economists, as well as Lithuanian scientists and politicians. The current income distribution is recognized as a factor causing negative socio-economic consequences. The imperfection of redistributive leverage in the economy has led to the concentration of excessive resources and material goods in small population groups. The authors' research shows that economic inequality impedes economic growth and quality of life of the population.

The distribution of wealth in various European countries is calculated by means of different methods: surveys, data relating to property taxes, the property multiplier method. The authors have discussed the data collected during the survey of Lithuanian residents and selected to use the method of evaluation of wealth distribution.

$96.6 \%$ of the respondents who own their dwelling-place are pensioners, $86.4 \%$ of the respondents who own their dwelling-place receive income from their own enterprises or farming activity and $81.1 \%$ of the respondents who live in their own dwelling-place work as contract employees. A considerable part of the respondents who receive 
unemployment benefits, disability pensions or other social benefits (82.3\%) also have their own private dwelling-places.

The pessimistic tendency in society is illustrated by the respondents' self-attribution to different socio-economic groups: some respondents tend to assess their material condition with sufficient criticism, although the assets owned by them, as indicated in the survey, enable them to meet their essential needs.

Those who refer to themselves as disadvantaged and being unable to live a respectable life have at their disposal the following: $90.6 \%$ of such respondents live in their own private dwelling-place, $43.5 \%$ of such respondents own a car, $33 \%$ of the respondents have their own land parcel (household holding) larger than 5 ares.

The respondents who refer to themselves as belonging to the poorest sections of society and being unable to meet their daily needs have at their disposal the following: $82.2 \%$ of them live in their own dwelling-places, $11.1 \%$ of them own a car and $15.6 \%$ of them own a private land parcel (household holding) larger than 5 ares.

$82.4 \%$ of those who refer to themselves as belonging to the middle class and having enough resources (money) to lead a normal life and, respectively, 83.5\% of those who refer to themselves as belonging to the middle class and having to limit their expenses actually live in their own private dwelling-places. Similarly, $36 \%$ of the former and $37.1 \%$ of the latter have at their disposal a private land parcel larger than 5 ares.

The value of the assets owned by representatives of these socio-economic groups differs by 16.9 times. Based on the data provided by the respondents, it is clear that the minimum statistic value of a single dwelling-place ranges between EUR 9990 in decile I and up to EUR 169200 in decile X. However, comparing the average prices of dwellingplaces in deciles I and X, the difference amounts to 7.2 times.

Based on the tentative evaluation made by the authors and considering the market value of accommodation, land, durable goods and other types of assets in 2016, also based on the data collected during the survey that have been mostly used in order to determine the average value of a single household, it has been revealed that the distribution of wealth exceeds the limit of income and consumption distribution established by various statistical organisations and by the authors themselves. The decile ratio (in relation to deciles I and $\mathrm{X}$ ) equals to 40.8 , thus, it considerably exceeds the level of income and consumption inequality.

Based on the answers provided by the respondents that are considered to belong to the upper class, it has been determined that $10 \%$ of the richest Lithuanians have at their disposal about $34.8 \%$ of overall wealth in Lithuania and $1 \%$ of the richest Lithuanians own $8.9 \%$ of overall wealth in Lithuania. Moreover, having estimated the differences among adjacent deciles, it is evident that the largest difference exists between deciles $X$ and IX as well as between deciles I and II (2.8 times). These findings mean that such significant differences among marginal deciles have a significant impact on the indicators of wealth inequality.

Based on the calculations of the Gini coefficient of wealth inequality in rural areas, cities and metropolitan areas in Lithuania as well as in Lithuania in general, also bearing in mind that the survey included only the respondents that have their own dwelling-place, without taking into account the respondents that do not own accommodation or any other 
type of real estate, land, financial assets, durable goods, works of art or intangible assets, it is evident that wealth inequality between households is rather high, as the Gini coefficient exceeds the limit of 0.3 , i.e., the theoretical margin of this particular coefficient. Thus, having considered the limits of this method of evaluating wealth inequality, it might be stated that the real level of wealth inequality in Lithuania already exceeds the existing levels of income and consumption inequality.

\section{References}

DEATON, A. (2015). Great Escape: Health, Wealth, and the Origins of Inequality. Princeton University Press, 360 p., ISBN 978-0691165622.

PIKETTY, T. (2014). Capital in the Twenty-First Century. Harvard University Press, 685 p., ISBN 978-0-674-43000-6. https://doi.org/10.4159/9780674369542

PIKETTY, T., SAEZ, E. (2003). Income Inequality In The United States, 1913-1998. Quarterly Journal of Economics, v118 (1,Feb), 1-39. https://doi.org/10.1162/00335530360535135

PIKETTY, T., SAEZ, E. The Evolution of Top Incomes: A Historical and International Perspective. American Economic Review: Papers and Proceedings, 96, 2 (May 2006). https://doi.org/10.1257/000282806777212116

PIKETTY, T., ZUCMAN, G. (2015). Wealth and Inheritance in the Long Run. Handbook of Income Distribution, vol. 2. https://doi.org/10.1016/B978-0-444-59429-7.00016-9

RAKAUSKIENĖ, O. G., PUŠKORIUS, S., DIRŽYTĖ, A., SERVETKIENĖ, V., et al. (2017). Socialinè ekonominè nelygybė Lietuvoje [Socio-economic inequality in Lithuania]. Vilnius: Mykolas Romeris University, 476 p., ISBN 978-9955-19-869-7.

RAKAUSKIENĖ, O. G., ŠTREIMIKIENĖ, D., SERVETKIENĖ, V., et al. (2015). Gyvenimo kokybès matavimo rodikliu sistema ir vertinimo modelis [Quality of life measurement indicator system and assessment model]. Vilnius: Mykolas Romeris University, 760 p., ISBN 978-19-713-3.

REICH, R. B. (2010). Aftershock: The Next Economy and America's Future. Knopf, 192 p. ISBN 978-0307592811.

SALVERDA, W., NOLAN, B., SMEEDING, T. M. et al. (2013), The Oxford Handbook of Economic Inequality. Oxford University Press, 736 p., ISBN 978-0-19-960606-1.

STIGLITZ, J. E. (2015). The Great Divide, Penguin Books, 428 p., ISBN 978-0-141-98122-2.

STIGLITZ, J. E. (2015). Rewriting the Rules of the American Economy. An Agenda for Growth and Shared Prosperity. W. W. Norton \& Company, 256 p. ISBN 978-0393353129.

STIGLITZ, J., SEN A., FITOUSSI, J. P. (2009). The Measurement of Economic Performance and Social Progress Revisited. Fichier pdf, 390 Ko.

THE WORLD BANK (2011). The Changing Wealth of Nations: Measuring sustainable development in the new millennium. Washington DC, The World Bank. 